\title{
Tick-borne pathogens in ticks collected from birds in Taiwan
}

\author{
Chi-Chien Kuo ${ }^{1 *}{ }^{+}$, Yi-Fu Lin ${ }^{2 \dagger}$, Cheng-Te Yao ${ }^{3}$, Han-Chun Shih ${ }^{4}$, Lo-Hsuan Chung ${ }^{4}$, Hsien-Chun Liao ${ }^{4}$, \\ Yu-Cheng $\mathrm{Hsu}^{5^{*}}$ and Hsi-Chieh Wang ${ }^{4^{*}}$
}

\begin{abstract}
Background: A variety of human diseases transmitted by arthropod vectors, including ticks, are emerging around the globe. Birds are known to be hosts of ticks and can disperse exotic ticks and tick-borne pathogens. In Taiwan, previous studies have focused predominantly on mammals, leaving the role of birds in the maintenance of ticks and dissemination of tick-borne pathogens undetermined.
\end{abstract}

Methods: Ticks were collected opportunistically when birds were studied from 1995 to 2013. Furthermore, to improve knowledge on the prevalence and mean load of tick infestation on birds in Taiwan, ticks were thoroughly searched for when birds were mist-netted at seven sites between September 2014 and April 2016 in eastern Taiwan. Ticks were identified based on both morphological and molecular information and were screened for potential tick-borne pathogens, including the genera Anaplasma, Babesia, Borrelia, Ehrlichia and Rickettsia. Finally, a list of hard tick species collected from birds in Taiwan was compiled based on past work and the current study.

Results: Nineteen ticks (all larvae) were recovered from four of the 3096 unique mist-netted bird individuals, yielding a mean load of 0.006 ticks/individual and an overall prevalence of $0.13 \%$. A total of 139 ticks from birds, comprising 48 larvae, 35 nymphs, 55 adults and one individual of unknown life stage, were collected from 1995 to 2016, and 11 species of four genera were identified, including three newly recorded species (Haemaphysalis wellingtoni, Ixodes columnae and Ixodes turdus). A total of eight tick-borne pathogens were detected, with five species (Borrelia turdi, Anaplasma sp. clone BJ01, Ehrlichia sp. BL157-9, Rickettsia helvetica and Rickettsia monacensis) not previously isolated in Taiwan. Overall, 16 tick species of five genera have been recorded feeding on birds, including nine species first discovered in this study.

Conclusion: Our study demonstrates the paucity of information on ticks of birds and emphasizes the need for more research on ticks of birds in Taiwan and Southeast Asia. Moreover, some newly recorded ticks and tick-borne pathogens were found only on migratory birds, demonstrating the necessity of further surveillance on these highly mobile species.

Keywords: Birds, Migratory birds, Ticks, Tick-borne pathogens, Taiwan

\footnotetext{
* Correspondence: cckuo@ntnu.edu.tw; ycsheu@mail.ndhu.edu.tw;

sjwang@cdc.gov.tw

${ }^{\dagger}$ Equal contributors

'Department of Life Science, National Taiwan Normal University, Taipei,

Taiwan

${ }^{5}$ Department of Natural Resources and Environmental Studies, National Dong

Hwa University, Hualien, Taiwan

${ }^{4}$ Center for Diagnostics and Vaccine Development, Centers for Disease

Control, Ministry of Health and Welfare, Taipei, Taiwan

Full list of author information is available at the end of the article
} 


\section{Background}

Ticks transmit the largest number of pathogens among all arthropod disease vectors and are second only to mosquitoes in their significance for human health. Moreover, several tick-borne diseases are expanding rapidly, such as anaplasmosis, babesiosis, Lyme disease, spotted fever and tick-borne encephalitis [1-4].

Ticks typically have four life stages: egg, larva, nymph and adult; a single blood meal from vertebrates is necessary for the larva and nymph to molt into the next life stage and for the adult female to lay eggs [5]. Small mammals are often one of the primary hosts for immature ticks [6], but a growing number of studies have revealed the significance of birds as hosts, as well as the role migratory birds play in the long-distance dissemination of ticks and tick-borne pathogens [7-13]. For example, immature western black-legged ticks Ixodes pacificus, the principal vector responsible for Borrelia burgdorferi (sensu stricto) in California, can be found on more avian than mammalian species [14]. Likewise, a large number of bird species are hosts of Ixodes scapularis [15]. Many tick species have been found on migratory birds [16-21], demonstrating their ability to spread ticks over long distances. More importantly, pathogens transmitted by ticks might be imported through the migration of birds. For example, the tick-borne spotted fever group (SFG) rickettsiae have been detected in exotic ticks recovered from migratory birds in Louisiana [21] and Russia [22]. Migratory birds have also been implicated in the spread of a variety of tick-borne diseases by carrying pathogen-infected ticks, including Lyme disease and Lyme borreliosis [7, 23, 24], tick-borne encephalitis [25], babesiosis [26], anaplasmosis [27] and Crimean-Congo hemorrhagic fever [28].

Although birds play a significant role in the subsistence of some ticks and tick-borne pathogens, their importance varies among species. For example, birds foraging primarily on the ground are more likely to acquire ticks than species foraging in trees and shrubs [29]. Species residing in dense oak woodland are more frequently infested with ticks than species living in chaparral, grass or a mixture of oak woodland and grass [30]. A review article found that in North America, nonmigratory, ground-foraging birds are more likely to be carriers of ticks, and major tick carriers are almost all passerines [13]. Similarly, reservoir competence of Borrelia burgdorferi (s.s.), the etiological agent of Lyme disease, also differed greatly among avian species [31]. Identifying these principal avian host species involved in pathogen cycles can assist in a more effective control of tick-borne diseases.

In Taiwan, tick-borne pathogens that have been isolated from ticks include tick-borne SFG rickettsiae [32-35], Anaplasma and Ehrlichia [35], Bartonella [36-38], Borrelia spp. bacteria that might cause Lyme borreliosis $[39,40]$ and Cytauxzoon protozoans [35]. Ticks assayed in these studies, along with investigation or documentation of other tickhost associations in Taiwan [41-51], focused predominantly on mammals. The only study [52] that has focused on ticks of birds covered a large geographical area (Oriental, Palaearctic, Malagasy and Ethiopian regions) and provided little information on tick-bird associations in Taiwan. Knowledge of ticks on birds and the tick-borne pathogens that these ticks can harbor remains very limited, not only in Taiwan but also across Southeast Asia. In Malaysia, tick infestation has been examined for seven avian species, but no ticks have been found [53]. Similarly, 15 species of birds have been investigated in Thailand, but only four ticks have been collected on one avian species [54]. Information is also needed on the role of migratory birds in the importation of ticks and tick-borne pathogens that are likely of exotic origin. The aim of this study is to investigate tick infestation on birds in Taiwan, including both resident and migratory birds, and screen for pathogens harbored by these ticks. Ticks were collected from two sources: an opportunistic collection of ticks from mist-netted or wounded birds and a thorough examination of tick infestation on mist-netted birds; the latter was implemented to reveal the prevalence and load of tick infestation on birds. Finally, we updated the list of hard tick species (Ixodidae) collected from birds in Taiwan based on previous work and the current study.

\section{Methods}

\section{Collection of ticks on birds}

Ticks of birds were collected opportunistically during two avian studies in which investigation of ectoparasites was not the main purpose; that is, ticks were collected when they were incidentally noticed by the researchers. The first study took place between 1995 and 2008, with birds being caught primarily by mist-netting around Taiwan in preparation for voucher specimens to be archived in the Endemic Species Research Institute of Taiwan. The collected ticks were preserved in 75\% ethanol and were stored at room temperature. Among this collection of ticks, 12 have been morphologically identified and reported [51]. The other study took place during 20092013, with birds being mist-netted at seven sites in the Taroko National Park and its surrounding areas in eastern Taiwan (Fig. 1) for a long-term avian biodiversity monitoring project. These seven sites were (site name and elevation in meters above sea level) as follows: Chongde (28 m); Donghwa (41 m); Buluowan (370 m); Xibao (980 m); Lianhua Pond (1100 m); Luoshao (1200 m); and Hehuan Farm (2700 m) (Fig. 1). Because avian faunas vary with elevation in Taiwan [55], these sites, with an altitudinal difference of nearly $2700 \mathrm{~m}$, covered different avian species. These study sites also included different habitat types, such as forests, farmlands, old fields and grassland. 


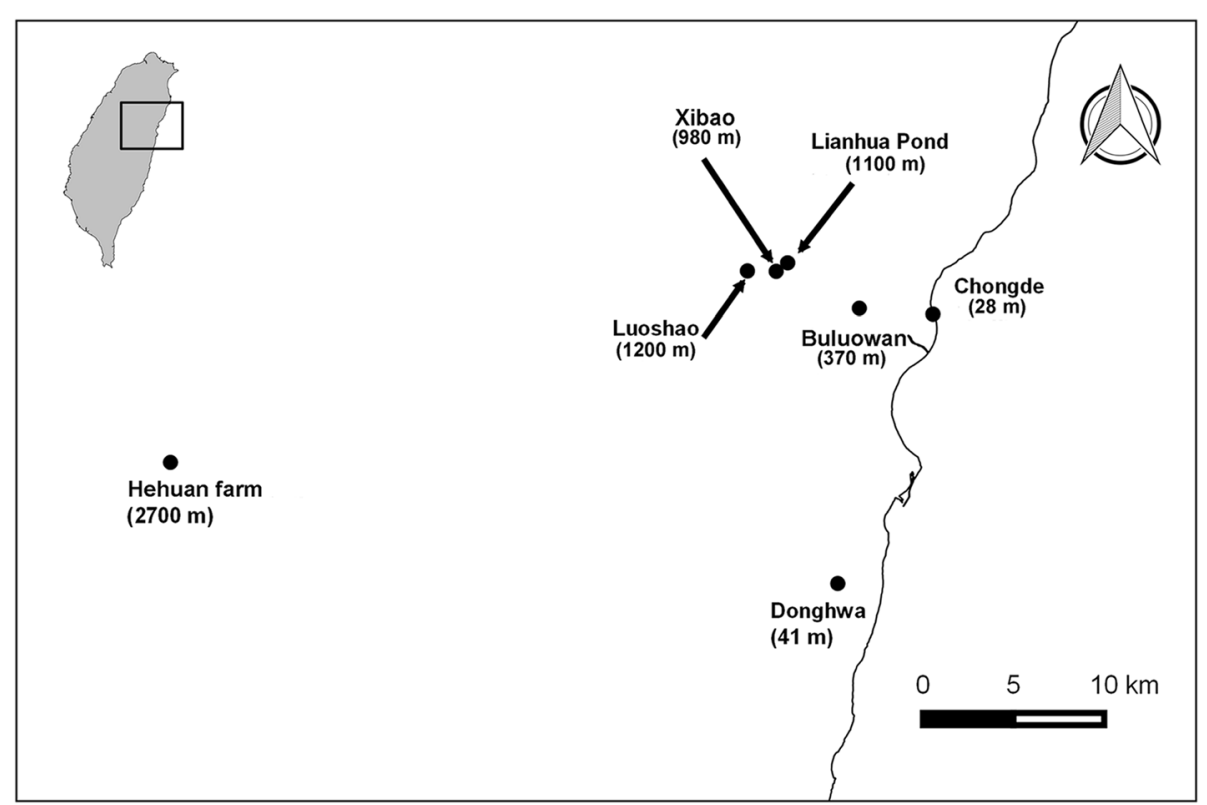

Fig. 1 Sites for mist-netting birds in Taiwan from September 2014 to April 2016. Dominant habitats for each site: Chongde: fallow fields; Donghwa: shrubland; Buluowan: forest; Xibao: fallow fields; Lianhua Pond: shrubland; Luoshao: fallow fields; Hehuan farm: forest

At each site, 6 to 10 mist nets were erected in the mornings and afternoons for two consecutive days, except for Donghwa, which was surveyed for two consecutive mornings only. Once captured, birds were banded, and a selection of morphological characteristics was measured. Ectoparasites, including ticks and lice, were collected when they were incidentally noticed. Ectoparasites were preserved in $100 \%$ ethanol and stored at $-20^{\circ} \mathrm{C}$.

Because infested ticks might have been overlooked in the above-mentioned opportunistic collections, to improve knowledge of the prevalence (i.e. the number of infested birds divided by the total number of the bird individuals studied) and mean load (i.e. the total number of ticks divided by the total number of the bird individuals studied) of tick infestation on birds in Taiwan, from September 2014 to April 2016, birds mist-netted at the same seven study sites in eastern Taiwan (Fig. 1) were thoroughly (instead of opportunistically) examined for infestations of ticks. Ticks were also preserved in 100\% ethanol and stored at $-20{ }^{\circ} \mathrm{C}$. The number of mist nets erected and days of survey at each study site were the same as for the 2009-2013 period. However, the frequency of surveys varied among the study sites due to the difficulty of accessing some sites or less sampling was implemented in sites with few birds trapped. Because migratory birds stopped over in Taiwan from September to April of the following year, the sampling period (September 2014 to April 2016) included two migratory seasons and a 20-month-long examination of resident birds. Wounded birds or birds accidently trapped by farmers during this survey period were also carefully examined for tick infestations. In this study, scientific names of birds and the division of migratory and resident birds follow Clements et al. [56].

\section{Identification of tick species}

Ticks were examined under a dissecting microscope (Leica MZ12) and morphologically identified to species using published keys $[57,58]$. When unrecognized, ticks were molecularly identified by comparing $12 \mathrm{~S}$ rDNA and $16 \mathrm{~S}$ rDNA sequences (primers provided in Table 1) with known species - following Black \& Piesman [59] and Beati \& Keirans [60]. The PCR products were purified using the QIAquick Gel Extraction Kit (Qiagen, Valencia, USA), and DNA sequencing was carried out using the ABI 3730XL DNA sequencer (Applied Biosystems, Foster City, USA) according to the manufacturer's protocol. The PCR products were sequenced twice in each direction and were searched for resemblance to known tick species by using the Basic Local Alignment Search Tool (BLAST) [61]. Representative sequences are submitted in the GenBank database under accession numbers MG283136 (Haemaphysalis wellingtoni), MG283137 (Ixodes columnae), and MG283138 (Ixodes turdus).

\section{Pathogen identification in ticks}

Because there are very few collections of ticks of birds in Taiwan, and due to the necessity that ticks be destroyed to be assayed for pathogen infection, only a portion of tick samples was obtained for pathogen detection, with another portion of tick specimens being saved as voucher specimens. When a bird was infested with more 
Table 1 Primers for tick species and tick-borne pathogen detections in hard ticks (Ixodidae) of birds in Taiwan

\begin{tabular}{|c|c|c|c|c|c|c|}
\hline & Gene target & Primers & Sequences $\left(5^{\prime}-3^{\prime}\right)$ & Product size (bp) & Method & Reference \\
\hline \multirow[t]{7}{*}{ Tick species } & \multirow[t]{2}{*}{ 12S rRNA gene } & $\mathrm{T} 1 \mathrm{~B}$ & AAACTAGGATTAGATACCCT & \multirow[t]{2}{*}{379} & \multirow[t]{2}{*}{ PCR } & \multirow[t]{2}{*}{ [60] } \\
\hline & & T2A & AATGAGAGCGACGGGCGATGT & & & \\
\hline & \multirow[t]{5}{*}{$16 \mathrm{~S}$ rRNA gene } & $16 S+1$ & CTGCTCAATGATIIITIAAATTGCTGTGG & \multirow[t]{5}{*}{452} & \multirow[t]{5}{*}{ PCR } & \multirow[t]{5}{*}{ [59] } \\
\hline & & $16 \mathrm{~S}-1$ & CCGGTCTGAACTCAGATCAAGTA & & & \\
\hline & & BmR1 & TGTTATTGCCTTACACTTCCTTGC & & & \\
\hline & & $\mathrm{BmF2}$ & ACGGCTACCACATCTAAGGAAGGC & & & \\
\hline & & BmR2 & TCTCTCAAGGTGCTGAAGGA & & & \\
\hline \multirow{2}{*}{$\begin{array}{l}\text { Anaplasma spp. and } \\
\text { Ehrlichia spp. }\end{array}$} & \multirow[t]{2}{*}{ 16S rRNA gene } & EHR 16SD & GGTACC(C/T)ACAGAAGAAGTCC & \multirow[t]{2}{*}{306} & \multirow[t]{2}{*}{ Real time PCR } & \multirow[t]{2}{*}{ [119] } \\
\hline & & EHR 16SR & TAGCACTCATCGTTTACAGC & & & \\
\hline \multirow[t]{9}{*}{ Rickettsia spp. } & \multirow[t]{5}{*}{ OmpB } & rompB OF & GTAACCGGAAGTAATCGTTCGTAA & \multirow[t]{5}{*}{426 or 250} & \multirow[t]{5}{*}{ Nested PCR } & \multirow[t]{9}{*}{ [120] } \\
\hline & & rompB OR & GCTTTATAACCAGCTAAACCACC & & & \\
\hline & & rompB SFG IF & GTTTAATACGTGCTGCTAACCAA & & & \\
\hline & & $\mathrm{SFG} / \mathrm{TG} \mathrm{IR}$ & GGTTTGGCCCATATACCATAAG & & & \\
\hline & & rompB TG IF & AAGATCCTTCTGATGTTGCAACA & & & \\
\hline & \multirow[t]{4}{*}{ gltA } & RpCS.877p & GGGGGCCTGCTCACGGCGG & \multirow[t]{4}{*}{338} & \multirow[t]{4}{*}{ Nested PCR } & \\
\hline & & RpCS.1258n & AATGCAAAAAGTACAGTGAACA & & & \\
\hline & & RpCS.896 & GGCTAATGAAGCAGTGATAA & & & \\
\hline & & RpCS.1233n & GCGACGGTATACCCATAGC & & & \\
\hline \multirow[t]{4}{*}{ Borrelia spp. } & \multirow[t]{4}{*}{$\operatorname{rrf(5S)-rrl(23S)}$} & $5 S-F$ & CGACCTTCTTCGCCTTAAAGC & \multirow[t]{4}{*}{$226-266$} & \multirow[t]{4}{*}{ Nested PCR } & \multirow[t]{4}{*}{ [121] } \\
\hline & & $23 S-R$ & TAAGCTGACTAATACTAATTACCC & & & \\
\hline & & $5 S-r r f$ & CTGCGAGTTCGCGGGAGA & & & \\
\hline & & $23 S-r r l$ & TCCTAGGCATTCACCATA & & & \\
\hline \multirow[t]{4}{*}{ Babesia spp. } & \multirow[t]{4}{*}{ 18S rRNA gene } & BmF1 & GCGATGTATCATTCAAGTTTCTG & \multirow[t]{4}{*}{700} & \multirow[t]{4}{*}{ Nested PCR } & \multirow[t]{4}{*}{ [122] } \\
\hline & & BmR1 & TGTTATTGCCTTACACTTCCTTGC & & & \\
\hline & & $\mathrm{BmF2}$ & ACGGCTACCACATCTAAGGAAGGC & & & \\
\hline & & $\mathrm{BmR2}$ & TCTCTCAAGGTGCTGAAGGA & & & \\
\hline
\end{tabular}

than one tick of the same species (based on morphological identification), about half of the specimens were selected to be assayed for pathogen infection. We also investigated pathogens in those unrecognized ticks that required molecular species identification.

The screened tick-borne pathogens occur in Taiwan or in nearby countries along the bird migration routes. A total of five groups of pathogens (and the potentially resultant human diseases) were assayed: Anaplasma (causative agent of anaplasmosis), Ehrlichia (causative agent of ehrlichiosis), Rickettsia (SFG rickettsiae), Borrelia (causative agent of Lyme disease) and Babesia (causative agent of babesiosis). Primers and methods for amplifying fragments of these pathogens were provided in Table 1 . The PCR protocol also followed the manufacturer's instructions, and positive samples were sequenced to identify potential microbial species with a resemblance to known species based on BLAST. Representative sequences are submitted in the GenBank database under accession numbers MG434346 (Borrelia turdi), MG346222
(Anaplasma sp. clone BJ01) and MG346223 (Ehrlichia sp. BL157-9).

\section{Published tick species on birds in Taiwan}

We compiled a list of hard ticks on birds in Taiwan based on published papers, books, theses and the current study. Papers were searched in PubMed (US National Library of Medicine) and Google Scholar using the keywords "ticks" and "Taiwan," supplemented with a perusal of references in these papers. We searched for potential theses with the keyword "ticks" (both in Chinese and English) in the National Digital Library of Theses and Dissertations in Taiwan. Books were also searched for in Google Scholar using the keywords "ticks" and "Taiwan" (both in Chinese and English), and by identifying references in related papers.

\section{Statistical analyses}

When comparing frequency of tick infestation on migratory vs resident birds, a Chi-square test was applied in SPSS version 19.0 (Armonk, NY: IBM Corp.). 


\section{Results}

Between September 2014 and April 2016, the seven study sites were mist-netted for a total of 56 times, with each site surveyed 2-17 times (Chongde: 2; Donghwa: 12; Buluowan: 2; Xibao: 5; Lianhua Pond: 10; Luoshao: 17; Hehuan Farm: 8). A total of 4145 captures of 3096 individuals of 86 bird species (including 74 individuals of wounded or accidently trapped birds) were examined for tick infestations. Of these, 2455 individuals were captured only once, and the remaining 641 individuals were captured 2-8 times. These birds included 2406 individuals of 55 resident species and 690 individuals of $31 \mathrm{mi}-$ gratory species (Additional file 1: Table S1). Only larval (but not nymphal and mature) ticks were collected, and a total of 19 larval ticks were recovered from 4 of these 3096 bird individuals, with a mean load of 0.006 ticks/individual and a prevalence of $0.13 \%$. These ticks belonged to Haemaphysalis doenitzi and Ixodes columnae, and were collected from one resident Sinosuthora webbiana (with $14 \mathrm{H}$. doenitzi), one resident S. webbiana (with one I. columnae), one migratory Emberiza spodocephala (with one I. columnae) and one migratory Turdus pallidus (with 3 I. columnae). The mean load of ticks was the same in resident birds (0.006 ticks/individual) as in migratory birds (0.006 ticks/individual). Prevalence of tick presence was more than three times higher in migratory birds $(0.29 \%)$ than in resident birds $(0.08 \%)$, although the difference was not statistically significant (Chisquare test: $\left.\chi^{2}=2.0, d f=1, P=0.16\right)$.

Overall, 139 ticks collected from birds, comprising 48 larvae, 35 nymphs, 55 adults and one individual of unknown life stage, were examined. These included 19 larval ticks collected between September 2014 and April 2016 in eastern Taiwan, and 120 ticks opportunistically collected from two avian studies implemented during 1995-2008 around Taiwan (83 ticks collected from 1268 bird individuals; mean load of 0.065 ticks/individual) and 2009-2013 in eastern Taiwan (37 ticks from 6343 bird individuals; mean load of 0.006 ticks/individual). A total of 11 species of four genera (Amblyomma spp., H. doenitzi, $H$. flava, $H$. formosensis, $H$. hystricis, $H$. ornithophila, $H$. wellingtoni, I. columnae, I. granulatus, I. nipponensis, I. turdus and Rhipicephalus haemaphysaloides) were identified, including three newly recorded species in Taiwan $(H$. wellingtoni, I. columnae and I. turdus) and six species collected from birds in Taiwan for the first time ( $H$. flava, $H$. formosensis, $H$. hystricis, I. granulatus, I. nipponensis and $R$. haemaphysaloides). The identity of the three newly recorded species has been validated with $100 \%$ identity to the nucleotide sequence deposited in GenBank ( $H$. wellingtoni: AB819221; I. columnae: AB819233; I. turdus: AB819259). Ticks were collected from 19 bird species, including seven migratory species, notably the thrush family
(Turdus chrysolaus, Turdus hortulorum, Turdus pallidus and Zoothera dauma) (Table 2). Haemaphysalis doenitzi was the most common species (42 ticks), comprising > 30\% of all collected ticks, followed by $H$. ornithophila (21 ticks), $H$. wellingtoni (17 ticks) and I. columnae (17 ticks) (Table 2). These four species accounted for nearly $70 \%$ of all ticks. In comparison, I. columnae infested the most diverse host species (9 species), followed by $I$. turdus (4 species) and $H$. doenitzi (3 species) (Table 2). A few immature ticks (16 individuals) could at best be identified to genus (Amblyomma, Ixodes or Haemaphysalis species) based on morphology and molecular methods (Table 2).

We found 10 papers containing information on hard ticks of birds in Taiwan (Table 3). A total of five genera and 16 species of hard ticks were identified based on the current and past studies, including nine species not previously discovered in Taiwan. The genus Haemaphysalis (9 species) was most represented, followed by Ixodes ( 5 species); each of the Dermacentor and Rhipicephalus contained one species and Amblyomma ticks could not be identified to the species level (Table 3).

A total of 85 ticks were individually assayed for pathogen infection, including 5 Amblyomma spp., $24 \mathrm{H}$. doenitzi, $1 \mathrm{H}$. flava, $1 \mathrm{H}$. formosensis, $9 \mathrm{H}$. hystricis, $6 \mathrm{H}$. ornithophila, $8 \mathrm{H}$. wellingtoni, 3 Haemaphysalis spp., 17 I. columnae, 4 I. granulatus, 1 I. nipponensis, 5 I. turdus, and $1 R$. haemaphysaloides. One Anaplasma species (Anaplasma sp. clone BJ01), one Babesia species (Ba. microti), two Borrelia species (Bo. valaisiana and Bo. turdi), one Ehrlichia species (Ehrlichia sp. BL157-9) and three Rickettsia species ( $R$. conorii, R. helvetica and $R$. monacensis) were successfully sequenced from six tick species (Table 4). Rickettsia helvetica, or a closely related species, was most frequently identified (8 times, all from the tick I. columnae), followed by Bo. valaisiana (3 times from I. granulatus) and Bo. turdi (twice from I. turdus). The other five pathogen species were detected only once (Table 4). Two-thirds of the 18 detections of pathogens were on ticks collected from migratory birds, particularly the pale thrush (T. pallidus) (Table 4 ).

\section{Discussion}

This is one of the few studies focusing on bird-derived ticks and their pathogens in Southeast Asia, showing 11 tick species, of which $H$. wellingtoni, I. columnae and $I$. turdus are new records for Taiwan, and $H$. flava, $H$. formosensis, $H$. hystricis, I. granulatus, I. nipponensis and $R$. haemaphysaloides have been collected from birds in Taiwan for the first time (but had been previously collected from mammals). In addition, eight pathogens have been detected in these ticks, among which Bo. turdi, Anaplasma sp. clone BJ01, Ehrlichia sp. BL157-9, R. helvetica and $R$. monacensis have not previously been identified in Taiwan. Migratory birds were found to host 
Table 2 Species of hard ticks (Ixodidae) and their bird hosts studied from 1995 to 2016 in Taiwan

\begin{tabular}{|c|c|c|}
\hline Tick species & No. of ticks & Avian host species (no. of birds the ticks were removed from; abundance of tick life \\
\hline \multicolumn{3}{|l|}{ Genus Amblyomma } \\
\hline Amblyomma spp. & 6 & Turnix suscitator $(1 ; 6 \mathrm{~L})$ \\
\hline \multicolumn{3}{|l|}{ Genus Haemaphysalis } \\
\hline Haemaphysalis doenitzi & 42 & Centropus bengalensis (10; 3N, 16A); Sinosuthora webbiana (1; 14L); Phasianus colchic \\
\hline Haemaphysalis flavab & 1 & Turdus pallidus ${ }^{\mathrm{C}}(1 ; 1 \mathrm{~N})$ \\
\hline Haemaphysalis formosensis ${ }^{\mathrm{b}}$ & 2 & Turdus hortulorum ${ }^{c}(1 ; 1 \mathrm{~N})$; Zoothera dauma ${ }^{\mathrm{c}}(1 ; 1 \mathrm{~N})$ \\
\hline Haemaphysalis hystricis ${ }^{\text {b }}$ & 12 & Pomatorhinus musicus $(1 ; 7 \mathrm{~N})$; Z. dauma ${ }^{\mathrm{c}}(3 ; 5 \mathrm{~N})$ \\
\hline Haemaphysalis ornithophila & 21 & Lophura swinhoii $(1 ; 4 \mathrm{~N}) ;$ T. pallidus $^{c}(1 ; 1 \mathrm{~A})$; Z. dauma ${ }^{c}(7 ; 16 \mathrm{~A})$ \\
\hline Haemaphysalis wellingtoni ${ }^{a}$ & 17 & Centropus sinensis $(1 ; 3 \mathrm{~L}, 3 \mathrm{~N}, 11 \mathrm{~A})$ \\
\hline Haemaphysalis spp. & 6 & $\begin{array}{l}\text { Alcippe morrisonia }(1 ; 1 \mathrm{~N}) ; \text { C. bengalensis }(1 ; 1 \mathrm{~N}) \text {; Otus spilocephalus }(1 ; 1 \mathrm{~L}) ; \\
\text { Parus monticolus }(1 ; 1 \mathrm{~L}) ; P \text {. colchicus }(1 ; 1 \mathrm{~N}) ; Z \text {. dauma }{ }^{c}(1 ; 1 \mathrm{~L})\end{array}$ \\
\hline \multicolumn{3}{|l|}{ Genus Ixodes } \\
\hline Ixodes columnae ${ }^{a}$ & 17 & $\begin{array}{l}\text { A. morrisonia }(1 ; 2 \mathrm{~L}) \text {; Horornis acanthizoides }\left(1 ; 1 \text { ?); Emberiza spodocephala }{ }^{\mathrm{c}}(1 ; 1 \mathrm{~L}) \text {; }\right. \\
\text { Ficedula hyperythra }(1 ; 1 \mathrm{~L}) ; \mathrm{L} \text {. swinhoii }(1 ; 3 \mathrm{~L}) \text {; S. webbiana }(2 ; 2 \mathrm{~L}) ; \\
\text { Tarsiger indicus }(1 ; 2 \mathrm{~L}) ; T \text {. pallidus }{ }^{\mathrm{C}}(2 ; 4 \mathrm{~L}) ; \text { Yuhina brunneiceps }(1 ; 1 \mathrm{~L})\end{array}$ \\
\hline Ixodes granulatus ${ }^{\mathrm{b}}$ & 5 & E. spodocephalac $(4 ; 1 \mathrm{~L}, 3 \mathrm{~N}) ;$ T. pallidus ${ }^{\mathrm{C}}(1 ; 1 \mathrm{~A})$ \\
\hline Ixodes nipponensis ${ }^{\mathrm{b}}$ & 1 & Phylloscopus fuscatus ${ }^{\complement}(1 ; 1 \mathrm{~N})$ \\
\hline Ixodes turdus ${ }^{a}$ & 4 & $\begin{array}{l}\text { Anthus hodgsoni } i^{\mathrm{C}}(1 ; 1 \mathrm{~A}) \text {; Prinia inornata }(1 ; 1 \mathrm{~N}) \text {; Turdus chrysolaus }{ }^{\mathrm{c}}(1 ; 1 \mathrm{~N}) \text {; } \\
\text { T. pallidus }{ }^{\mathrm{N}}(1 ; 1 \mathrm{~A})\end{array}$ \\
\hline Ixodes spp. & 4 & $\begin{array}{l}\text { Tarsiger johnstoniae }(1 ; 1 \mathrm{~L}) \text {; Locustella alishanensis }(1 ; 1 \mathrm{~N}) \text {; } \\
\text { Cyanoderma ruficeps }(1 ; 1 \mathrm{~L}) ; \text { T. pallidus }{ }^{\complement}(1 ; 1 \mathrm{~L})\end{array}$ \\
\hline
\end{tabular}

Genus Rhipicephalus

Rhipicephalus haemaphysaloides ${ }^{b}$

T. chrysolaus $^{\mathrm{c}}(1 ; 1 \mathrm{~A})$

Abbreviations: $L$ larva, $N$ nymph, $A$ adult

${ }^{\text {a }}$ Newly recorded species in Taiwan

${ }^{b}$ First record on birds in Taiwan

${ }^{c}$ Migratory species

infected ticks and may play a role in disseminating pathogens. Our study demonstrates the paucity of information on ticks of birds and emphasizes the need for more research on ticks of birds in Taiwan.

Haemaphysalis wellingtoni, I. columnae and I. turdus have not previously been recorded in Taiwan, and this could be due to the limited research on ticks of birds, rather than a rare occurrence of these tick species in Taiwan, because birds are the primary hosts of these three species [62] and these ticks were repeatedly collected from birds or infested birds in large numbers (Table 2). For example, $17 \mathrm{H}$. wellingtoni were found on a resident, ground-foraging coucal Centropus sinensis in a small islet (Kinmen) near mainland China. Ixodes columnae has been found on various bird species in Taiwan, including both resident and migratory birds. Ixodes turdus was collected from four avian species: three migratory birds and one resident bird. This tick species has also been found on migratory birds in Japan [63] and Korea [20, 27], suggesting that migratory birds can potentially disperse $I$. turdus across countries.
The ticks H. flava, H. formosensis, H. hystricis, I. granulatus, I. nipponensis and $R$. haemaphysaloides have previously been found feeding on mammals in Taiwan, but not on birds. Mammals are the predominant hosts of these six tick species, although $H$. flava and I. granulatus can also be collected from birds [62]. Indeed, except for $H$. hystricis and I. granulatus, the other four species were rarely collected from birds (less than two tick individuals) (Table 2). Less frequent occurrence on birds and the lack of research on ticks of birds in Taiwan help explain why these six tick species were not previously found on birds. Haemaphysalis flava was collected from several mammal species in Taiwan, including boars, deer and dogs [42], and this species has been repeatedly collected from birds in Japan, particularly the migratory true thrushes (Turdus spp.) and buntings (Emberiza spp.) [64]; likewise, we found a nymphal $H$. flava on a migratory T. pallidus. Both $H$. formosensis and $H$. hystricis have been collected from mammals in Taiwan, particularly rodents [50]. Our study reveals that migratory birds are also the hosts of $H$. formosensis; in addition, we 
Table 3 Lists of species of hard ticks (Ixodidae) and their bird hosts known to occur in Taiwan

\begin{tabular}{|c|c|c|}
\hline Tick species & Avian host species & Source \\
\hline \multicolumn{3}{|l|}{ Genus Amblyomma } \\
\hline Amblyomma spp. & Turnix suscitator & {$[51]$; this study } \\
\hline \multicolumn{3}{|l|}{ Genus Dermacentor } \\
\hline Dermacentor taiwanensis & Bambusicola thoracica & {$[47]$} \\
\hline \multicolumn{3}{|l|}{ Genus Haemaphysalis } \\
\hline Haemaphysalis bispinosa & Gallus gallus & {$[46]$} \\
\hline Haemaphysalis doenitzi & $\begin{array}{l}\text { Bambusicola thoracica; Centropus bengalensis; Psilopogon nuchalis; } \\
\text { Sinosuthora webbiana; Phasianus colchicus; Pomatorhinus musicus; } \\
\text { Zoothera dauma }\end{array}$ & {$[52]$; this study } \\
\hline Haemaphysalis flava ${ }^{\text {b }}$ & Turdus pallidus $^{c}$ & This study \\
\hline Haemaphysalis formosensis ${ }^{b}$ & Turdus hortulorum ; Z. dauma ${ }^{c}$ & This study \\
\hline Haemaphysalis hystricis ${ }^{\mathrm{b}}$ & Pomatorhinus musicus; Z. dauma ${ }^{c}$ & This study \\
\hline Haemaphysalis mageshimaensis & Hypsipetes amaurotis; Zosterops japonicus & {$[44]$} \\
\hline Haemaphysalis ornithophila & Arborophila crudigularis; Lophura swinhoii; T. pallidus ${ }^{c}$; Z. dauma ${ }^{c}$ & {$[43,45,46]$; this study } \\
\hline Haemaphysalis wellingtoni ${ }^{a}$ & Centropus sinensis & This study \\
\hline Haemaphysalis yeni & C. bengalensis & [48] \\
\hline Haemaphysalis spp. & $\begin{array}{l}\text { Alcippe morrisonia; C. bengalensis; Otus spilocephalus; Parus monticolus; } \\
\text { P. colchicus; Turnix suscitator; Z. dauma }{ }^{c}\end{array}$ & This study \\
\hline \multicolumn{3}{|l|}{ Genus Ixodes } \\
\hline Ixodes columnae ${ }^{a}$ & $\begin{array}{l}\text { A. morrisonia; Horornis acanthizoides; Emberiza spodocephalac; } \\
\text { Ficedula hyperythra; L. swinhoii; S. webbiana; Tarsiger indicus; T. pallidus; } \\
\text { Yuhina brunneiceps }\end{array}$ & This study \\
\hline Ixodes granulatus ${ }^{b}$ & E. spodocephalac; T. pallidus ${ }^{c}$ & This study \\
\hline Ixodes kuntzi & Sitta europaea & {$[41,42,46]$} \\
\hline Ixodes nipponensis ${ }^{b}$ & Phylloscopus fuscatus ${ }^{\mathrm{C}}$ & This study \\
\hline Ixodes turdus ${ }^{a}$ & Anthus hodgsonic; Prinia inornata; Turdus chrysolaus ${ }^{c}$; T. pallidus ${ }^{c}$ & This study \\
\hline Ixodes spp. & Tarsiger johnstoniae; Locustella alishanensis; Cyanoderma ruficeps; T. pallidus ${ }^{c}$ & This study \\
\hline \multicolumn{3}{|l|}{ Genus Rhipicephalus } \\
\hline Rhipicephalus haemaphysaloides ${ }^{b}$ & T. chrysolaus ${ }^{c}$ & This study \\
\hline
\end{tabular}

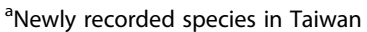

${ }^{b}$ First record on birds in Taiwan

${ }^{\mathrm{c}}$ Migratory species

collected 12 immature $H$. hystricis from birds, demonstrating that birds might not be occasional hosts of $H$. hystricis, as previously considered [62]. Ixodes granulatus is one of the most abundant and widespread tick species in Taiwan and infests a diverse set of rodent species [48, 50, 65]; in this study, five I. granulatus ticks have also been collected from migratory birds, suggesting that birds might also serve as major hosts of these generalist ticks. By contrast, there are very few records of I. nipponensis in Taiwan, with two adults recovered from cattle, and I. nipponensis was not definitely confirmed to be native to Taiwan [48]. Our study verifies that $I$. nipponensis did occur in Taiwan, although it was retrieved from a migratory bird and might not have yet been established in Taiwan. Ixodes nipponensis is distributed in temperate broadleaf and mixed forests [62] and is a common species in Japan [66] and Korea [67, 68]. Taiwan's subtropical climate may not be ideal for the subsistence of I. nipponensis, hence the failure to establish itself in Taiwan. Rhipicephalus haemaphysaloides is also a common ectoparasite on rodents of Taiwan [65]. Similar to $H$. hystricis, birds are deemed to be occasional hosts of R. haemaphysaloides [62], and indeed, we found only one adult $R$. haemaphysaloides on a migratory, ground-feeding T. chrysolaus.

In this study, Amblyomma ticks collected from a resident bird species could not be identified to species based on both molecular and morphological characteristics. In Taiwan, four Amblyomma species (A. cordiferum, A. geoemydae, A. helvolum and A. testudinarium; [48]) have been identified, among which, birds are known to be hosts of $A$. geoemydae and A. testudinarium [62]. Whether the ticks collected in this study belong to A. geoemydae or A. testudinarium needs further investigation. 
Table 4 Pathogen species or closely related species identified in hard ticks (lxodidae) collected from birds from 1995 to 2016 in Taiwan

\begin{tabular}{|c|c|c|}
\hline Pathogen species & Tick species (no. of detections in different life stages) & Avian host of ticks (no. of ticks) \\
\hline \multicolumn{3}{|l|}{ Protozoa } \\
\hline Babesia microti & Ixodes granulatus (1L) & Emberiza spodocephala ${ }^{c}(1)$ \\
\hline \multicolumn{3}{|l|}{ Bacteria } \\
\hline \multicolumn{3}{|l|}{ Order Spirochaetales } \\
\hline \multicolumn{3}{|l|}{ Family Spirochaetaceae } \\
\hline Borrelia valaisiana & Ixodes granulatus $\left(1 \mathrm{~L}, 2 \mathrm{~N}^{\mathrm{a}}\right)$ & E. spodocephalac (3) \\
\hline Borrelia turdi & Ixodes turdus $(1 \mathrm{~N}, 1 \mathrm{~A})$ & Turdus chrysolaus ${ }^{\mathrm{c}}(1) ;$ Turdus pallidus $^{\mathrm{c}}(1)$ \\
\hline \multicolumn{3}{|l|}{ Order Rickettsiales } \\
\hline \multicolumn{3}{|l|}{ Family Anaplasmataceae } \\
\hline Anaplasma sp. clone BJ01 & Haemaphysalis ornithophila (1N) & Lophura swinhoii (1) \\
\hline Ehrlichia sp. BL157-9 & Haemaphysalis flava $(1 \mathrm{~N})$ & T. pallidus ${ }^{\complement}(1)$ \\
\hline \multicolumn{3}{|l|}{ Family Rickettsiaceae } \\
\hline Rickettsia conorii & Haemaphysalis ornithophila (1A) & Zoothera daumac (1) \\
\hline Rickettsia helvetica & Ixodes columnae (8L $\left.{ }^{\mathrm{b}}\right)$ & $\begin{array}{l}\text { Alcippe morrisonia (1); Ficedula hyperythra (1); Lophura } \\
\text { swinhoii (1); Tarsiger indicus (1); T. pallidus }{ }^{c}(4)\end{array}$ \\
\hline Rickettsia monacensis & Ixodes nipponensis (1N) & Phylloscopus fuscatus (1) \\
\hline
\end{tabular}

Abbreviations: $L$ larva, $N$ nymph, $A$ adult

${ }^{a}$ The three Ixodes granulatus were removed from three different Emberiza spodocephala

${ }^{\mathrm{b}}$ Three of the eight Ixodes columnae were removed from the same individual Turdus pallidus

cMigratory species

Based on published studies on ticks of birds in Taiwan, a total of five genera and 16 species of hard ticks were found feeding on birds according to the current and past studies (Table 3). Among these, only seven species have previously been documented, and nine species were first identified in Taiwan based on this single study (Table 3). It is thus expected that more species will be discovered after further research on avian ectoparasites. Based on morphological characteristics, Amblyomma spp., Haemaphysalis campanulata and Haemaphysalis phasiana were reported to be collected from birds [51]. We identified those specimens through morphology and DNA sequences but confirmed them to be Amblyomma spp., $H$. ornithophila and $H$. doenitzi, respectively. Haemaphysalis campanulata and $H$. phasiana were thus excluded from the final list. However, it is suspected that $H$. phasiana might be synonymous to $H$. doenitzi (see remarks by [62]). Indeed, $16 \mathrm{~S}$ rDNA sequences retrieved from the GenBank database showed 99.5\% (400/402) similarity between $H$. doenitzi (GenBank: JF979402) collected in China [69] and H. phasiana (AB819220) collected in Japan [70]. Likewise, 16S rDNA sequences of the eight $H$. doenitzi assayed in this study were 96.598.5\% similar to the $H$. phasiana sequence archived in GenBank. Whether $H$. phasiana is synonymous with $H$. doenitzi should be resolved when more genetic data (e.g. $12 \mathrm{~S}$ rDNA sequence on $H$. phasiana lacking in GenBank) on both species are available.
Only 19 ticks were collected during the 2014-2016 study compared with 120 ticks collected from 1995 to 2013. A further analysis reveales that the mean load of ticks in eastern Taiwan is the same during 2014-2016 as for the 2009-2013 period (both mean load $=0.006$ ticks/ individual), but the mean load is more than 10-fold higher when birds were captured around Taiwan (mean load of 0.065, during 1995-2008 period) than when birds were captured in eastern Taiwan. The reason for much lower mean tick loads in eastern Taiwan remains to be investigated. In addition, only larval ticks were found during the 2014-2016 study, whereas ticks collected during 1995-2013 were composed primarily of nymphs and adults (29 larvae, 35 nymphs, 55 adults). Because nymphal and adult ticks are larger than the larvae (which are more difficult to notice), the difference in composition of the life stages could be due to ticks being thoroughly searched for during 2014-2016 but only opportunistically collected during 1995-2013. Therefore, it should be emphasized that the 1995-2013 collection is biased toward nymphs and adults, and occurrence of larvae is underestimated.

Ticks are primary vectors for the five parasitic genera (Anaplasma [71]; Babesia [72]; Borrelia [73]; Ehrlichia [71]; Rickettsia [2]) identified in ticks in this study. Among the six tick species in which eight microbial species have been detected (Table 4), only H. ornithophila does not bite humans [62], so people in Taiwan are at 
risk of infection from most of the identified tick-borne pathogens. In addition, although $H$. ornithophila feeds primarily on birds [62], other generalist ticks might help bridge the pathogen transmission from birds to humans.

Among the eight pathogens detected in ticks, $B a$. microti, Bo. valaisiana and $R$. helvetica have been detected in larval ticks (Table 4). Relative to $R$. helvetica, which can be vertically transmitted in ticks [74], transovarial transmission of Ba. microti and Bo. valaisiana has rarely been documented in ticks [75, 76]. This suggests that birds might be reservoirs of $\mathrm{Ba}$. microti and $\mathrm{Bo}$. valaisiana, and larval ticks can be infected when feeding on birds. Indeed, birds were shown to be the reservoirs of Bo. valaisiana [77, 78]. By contrast, although $\mathrm{Ba}$. microti has been detected in ticks collected from birds (e.g. [26, 79]), birds are not considered to be the reservoirs of $\mathrm{Ba}$. microti [80]. Our study nevertheless suggests that birds might play a role in the maintenance of $\mathrm{Ba}$. microti, although the possibility that the larval tick acquires the protozoan via co-feeding ticks cannot be ruled out.

Five pathogens, i.e. Bo. turdi, Anaplasma sp. clone BJ01, Ehrlichia sp. BL157-9, R. helvetica and R. monacensis, have not previously been identified in Taiwan. Borrelia turdi was first characterized in I. turdus on migratory E. spodocephala in Japan [81, 82], and later in $I$. turdus and I. nipponensis on migratory birds in Korea [27]. This spirochete has also been detected in ticks collected primarily from Turdus spp. birds in Europe, including Belgium [83], Norway [84], Poland [85], Portugal [86] and Spain [76, 87]. Birds have been demonstrated to be the reservoirs of Bo. turdi [78]. In the current study, we showed that Bo. turdi also occurred in Taiwan, and similarly, the spirochete was detected in I. turdus collected from migratory birds (T. chrysolaus and T. pallidus), suggesting that Bo. turdi might be spread by migratory birds, particularly the thrush. Nevertheless, although I. turdus can infest humans [62], until now, Bo. turdi has not been found to cause Lyme borreliosis in humans [88].

Anaplasma and Ehrlichia are rickettsiae belonging to the family Anaplasmataceae and are the causative agents of several emerging human and animal diseases [89, 90]. Anaplasma sp. clone BJ01 was first isolated from Haemaphysalis longicornis in China (GenBank: JN715833). This bacterium is closely related to uncultured Anaplasma spp. in Korea and USA; nevertheless, a high degree of dissimilarity in 16S rRNA sequences with known Anaplasma species might warrant its reclassification under a new genus [91]. Anaplasma phagocytophilum and a novel Anaplasma sp. have been detected in bird tissues [92-94], indicating that birds could potentially infect ticks with Anaplasma. Ehrlichia sp. BL157-9 was first identified in Hyalomma asiaticum from China [95], and was closely related to Ehrlichia sp. ERm58 in the Ehrlichia canis group recognized in Rhipicephalus muhsamae from Mali [96].
Likewise, Ehrlichia chaffeensis and an Ehrlichia species closely related to E. canis have been detected in birds [92, 93], implying that birds might be reservoirs of Ehrlichia. Whether Anaplasma sp. clone BJ01 and Ehrlichia sp. BL157-9 are pathogenic to humans remains to be determined.

Rickettsia helvetica is a tick-borne SFG rickettsia first characterized in Ixodes ricinus from Switzerland and later identified in several European countries [2]. While less reported, evidence of human or tick infection by $R$. helvetica has also been found in Asia, including Japan [97-99], Thailand [100], Laos [101] and Sakhalin Island of Russia [102]. A strain similar to $R$. helvetica has also been isolated from raccoon and sika deer in Japan [103, 104]. In this study, a strain closely related to $R$. helvetica has been repeatedly detected in $I$. columnae recovered from both migratory and resident birds, demonstrating that the potentially pathogenic $R$. helvetica [105] might have become established in Taiwan. This should concern physicians in Taiwan, particularly when I. columnae also bite humans [62]. Moreover, the fact that I. columnae has only been collected from birds in Taiwan and birds are potential reservoirs of $R$. helvetica $[106,107]$ emphasizes the need for more research on birds, their associated ticks and their effects on public health.

Rickettsia monacensis also belongs to SFG and was first isolated from I. ricinus in Germany [108]. This species is widespread in Europe and can cause disease in humans [105]. Rickettsiae closely related to $R$. monacensis were later identified from ticks in East and Southeast Asia, including China [109, 110], Korea [111] and Thailand [112]. Rickettsia monacensis has also been detected in bird tissue [94]. Akin to the finding in Korea [111], this study isolated a strain genetically close to $R$. monacensis from $I$. nipponensis. Because I. nipponensis is distributed mainly in temperate regions [62], and in this study, I. nipponensis was retrieved from one migratory bird, $R$. monacensis was likely imported through bird migration. Recently, severe fever with thrombocytopenia syndrome (SFTS), an emerging infectious disease caused by the SFTS virus and with a high mortality rate, has been detected in I. nipponensis in Korea [113, 114]. The occurrence of I. nipponensis in Taiwan, despite being rare, should thus warrant further scrutiny.

The role of birds, particularly migratory birds, in the spread of ticks and tick-borne pathogens has received much more recognition in recent decades [7, 13, 115-117]. In this study, several ticks and tick-borne pathogens were discovered for the first time in Taiwan, including some that were found only on migratory birds (the tick I. turdus; the pathogens Bo. turdi and Ehrlichia sp. BL157-9), although it remains unclear if this is due to a lack of studies on ectoparasites of birds (namely, the same ticks and pathogens might be found in resident birds after thorough 
surveillance). In addition, while some ticks and pathogens were previously recognized in Taiwan, it is unknown whether the same species of ticks (e.g. H. flava and $H$. formosensis) and tick-borne pathogens (e.g. Ba. microti and Bo. valaisiana) recovered from migratory birds were acquired in Taiwan or from other countries (where ticks acquired pathogens and then were carried by migratory birds to Taiwan), so that a cross-country genetic mixture in ticks and pathogens is likely to occur. Therefore, the significance of migratory birds in the spread of exotic ticks and tickborne pathogens in Taiwan, and whether these ticks and pathogens can become established in Taiwan, warrants further investigation. This is particularly true when the majority of migrant birds found in this study forage on the ground [118], which makes them more likely to acquire ticks compared with birds foraging in trees or shrubs $[13,29]$. Studies are also needed on the seasonality of ticks in Taiwan to assess which life stage of which tick species is more active during the bird migration season (September to April of the following year) and thus more likely to be dispersed. In eastern Taiwan, it has been demonstrated that rodents are infested with more $R$. haemaphysaloides in October and November than in the other studied seasons, and larvae peak from October to January [49], but information on the seasonality of nearly all other tick species in Taiwan remains very limited.

\section{Conclusion}

Our study demonstrates a paucity of knowledge on ticks of birds and their associated pathogens in Taiwan and Southeast Asia. Birds are capable of spreading ticks over long distances; moreover, pathogens harbored by ticks might differ when ticks were collected from birds vs mammals, with the latter much more frequently studied than the former in Taiwan. More research on ticks of birds is thus warranted, which can be facilitated with the integration of ornithologists in the studies of ticks.

\section{Additional file}

Additional file 1: Table S1. Species of birds and number of captures and unique individuals mist-netted between September 2014 and April 2016 in eastern Taiwan. (DOCX 16 kb)

\section{Acknowledgements}

We would like to thank the field workers for their help with mist-netting birds.

\section{Funding}

This study was financially supported by Taiwan Ministry of Science and Technology (MOST 104-2621-B-003-003) and National Taiwan Normal University (103091002) to C-CK. This article was subsidized by the National Taiwan Normal University (NTNU), Taiwan. The bird banding program was funded by the Taroko National Park to $\mathrm{Y}-\mathrm{CH}$.

\section{Availability of data and materials}

The data supporting the conclusions of this article are included within the article. The tick specimens are deposited in Center for Diagnostics and Vaccine Development, Centers for Disease Control, Taipei and Endemic Species Research Institute, Council of Agriculture, Nantou. Representative sequences are submitted in the GenBank database under accession numbers MG283136 (Haemaphysalis wellingtoni), MG283137 (Ixodes columnae),

MG283138 (Ixodes turdus), MG434346 (Borrelia turdi), MG346222 (Anaplasma sp. clone BJ01) and MG346223 (Ehrlichia sp. BL157-9).

\section{Authors' contributions}

C-CK conceived and coordinated the study. Y-CH and C-TY mist-netted birds and collected ticks. Y-FL and H-CW identified ticks based on morphology. H-CW, H-CS, L-HC and H-CL identified ticks based on molecular methods and detected pathogens in ticks. C-CK wrote the manuscript. All authors read and approved the final manuscript.

\section{Ethics approval}

Protocols of this study were approved by Taroko National Park and Council of Agriculture (No. TB1040000117) and all animal handling procedures met Taiwanese legal requirements.

\section{Consent for publication}

Not applicable.

\section{Competing interests}

The authors declare that they have no competing interests.

\section{Publisher's Note}

Springer Nature remains neutral with regard to jurisdictional claims in published maps and institutional affiliations.

\section{Author details}

'Department of Life Science, National Taiwan Normal University, Taipei, Taiwan. ${ }^{2}$ Department of Life Science, National Chung Hsing University, Taichung, Taiwan. ${ }^{3}$ Endemic Species Research Institute, Council of Agriculture, Chi-chi, Nantou, Taiwan. ${ }^{4}$ Center for Diagnostics and Vaccine Development, Centers for Disease Control, Ministry of Health and Welfare, Taipei, Taiwan. ${ }^{5}$ Department of Natural Resources and Environmental Studies, National Dong Hwa University, Hualien, Taiwan.

Received: 14 August 2017 Accepted: 13 November 2017

Published online: 25 November 2017

\section{References}

1. Parola P, Raoult D. Ticks and tickborne bacterial diseases in humans: an emerging infectious threat. Clin Infect Dis. 2001;32:897-928.

2. Parola P, Paddock CD, Raoult D. Tick-borne rickettsioses around the world: emerging diseases challenging old concepts. Clin Microbiol Rev. 2005;18: 719-56.

3. Durden LA. Taxonomy, host associations, life cycles and vectorial importance of ticks parasitizing small mammals. In: Morand S, Krasnov BR, Poulin R, editors. Micromammals and Macroparasites. From Evolutionary Ecology to Management. Tokyo: Springer Verlag; 2006. p. 91-102.

4. Pfäffle M, Littwin N, Muders SV, Petney TN. The ecology of tick-borne diseases. Int J Parasitol. 2013:43:1059-77.

5. Sonenshine DE. Biology of ticks, vol. 1. New York: Oxford University Press; 1991.

6. Horak I, Camicas JL, Keirans J. The Argasidae, Ixodidae and Nuttalliellidae (Acari: Ixodida): a world list of valid tick names. Exp Appl Acarol. 2002;28:27-54.

7. Ogden NH, Lindsay RL, Hanincova K, Barker IK, Bigras-Poulin M, Charron DF, et al. Role of migratory birds in introduction and range expansion of Ixodes scapularis ticks and of Borrelia burgdorferi and Anaplasma phagocytophilum in Canada. Appl Environ Microbiol. 2008;74:1780-90.

8. Gómez-Díaz E, Morris-Pocock JA, González-Solís J, McCoy KD. Trans-oceanic host dispersal explains high seabird tick diversity on Cape Verde islands. Biol Lett. 2012;8:616-9.

9. Hamer SA, Hickling GJ, Keith R, Sidge JL, Walker ED, Tsao Jl. Associations of passerine birds, rabbits, and ticks with Borrelia miyamotoi and Borrelia andersonii in Michigan, USA. Parasit Vectors. 2012;5:231.

10. Marsot M, Henry PY, Vourc'h G, Gasqui P, Ferquel E, Laignel J, et al. which forest bird species are the main hosts of the tick, Ixodes ricinus, the vector of 
Borrelia burgdorferi sensu lato, during the breeding season? Int J Parasitol. 2012;42:781-8.

11. Hasle G. Transport of ixodid ticks and tick-borne pathogens by migratory birds. Front Cell Infect Microbiol. 2013;3:48.

12. Léger E, Vourc'h G, Vial L, Chevillon C, McCoy K. Changing distributions of ticks: causes and consequences. Exp Appl Acarol. 2013;59:219-44.

13. Loss SR, Noden BH, Hamer GL, Hamer SAA. Quantitative synthesis of the role of birds in carrying ticks and tick-borne pathogens in North America. Oecologia. 2016;182:947-59.

14. Castro MB, Wright SA. Vertebrate hosts of Ixodes pacificus (Acari: Ixodidae) in California. J Vector Ecol. 2007;32:140-9.

15. Brinkerhoff RJ, Folsom-O'Keffe CM, Bent SJ, Tsao K, Barbour AG, Diuk-Wasser MA. Genotypic diversity of Borrelia burgdorferi strains detected in Ixodes scapularis larvae collected from north American songbirds. Appl Environ Microbiol. 2010;76:8265-8.

16. Pietzsch ME, Mitchell R, Jameson L, Morgan C, Medlock JM, Collins D, et al. Preliminary evaluation of exotic tick species and exotic pathogens imported on migratory birds into the British isles. Vet Parasitol. 2008;155:328-32.

17. Hasle G, Bjune G, Edvardsen E, Jakobsen C, Linnehol B, Røer JE, et al. Transport of ticks by migratory passerine birds to Norway. J Parasitol. 2009; 95:1342-51.

18. Jameson L, Morgan PJ, Medlock JM, Watola G, Vaux AGC. Importation of Hyalomma marginatum, vector of Crimean-Congo haemorrhagic fever virus, into the United Kingdom by migratory birds. Ticks Tick Borne Dis. 2012;3:95-9.

19. Nowak-Chmura M. Ixodes eldaricus Djaparidze, 1950 (Ixodidae) on migrating birds - reported first time in Poland. Vet Parasitol. 2012;186:399-402.

20. Choi CY, Kang CW, Kim EM, Lee S, Moon KH, MR O, et al. Ticks collected from migratory birds, including a new record of Haemaphysalis formosensis, on Jeju Island, Korea. Exp Appl Acarol. 2014;62:557-66.

21. Mukherjee N, Beati L, Sellers M, Burton L, Adamson S, Robbins RG, et al. Importation of exotic ticks and tick-borne spotted fever group rickettsiae into the United States by migrating songbirds. Ticks Tick Borne Dis. 2014;5:127-34.

22. Movila A, Alekseev AN, Dubinina HV, Toderas I. Detection of tick-borne pathogens in ticks from migratory birds in the Baltic region of Russia. Med Vet Entomol. 2013;27:113-7.

23. Ishiguro F, Takada N, Masuzawa T. Molecular evidence of the dispersal of Lyme disease Borrelia from the Asian continent to Japan via migratory birds. Jpn J Infect Dis. 2005;58:184-6.

24. Comstedt P, Bergstrom S, Olsen B, Garpmo U, Marjavaara L, Mejlon H, et al. Migratory passerine birds as reservoirs of Lyme borreliosis in Europe. Emerg Infect Dis. 2006;12:1087-95.

25. Waldenström J, Lundkvist A, Falk Kl, Garpmo U, Bergström S, Lindegren G, et al. Migrating birds and tick-borne encephalitis virus. Emerg Infect Dis. 2007:13:1215-8.

26. Capligina V, Salmane I, Keiss O, Vilks K, Japina K, Baumanis V, Ranka R, Prevalence of tick-borne pathogens in ticks collected from migratory birds in Latvia. Ticks Tick Borne Dis. 2014;5:75-81.

27. Kang JG, Kim HC, Choi CY, Nam HY, Chae HY, Chong ST, et al. Molecular detection of Anaplasma, Bartonella, and Borrelia species in ticks collected from migratory birds from Hong-do Island, Republic of Korea. Vector Borne Zoonotic Dis. 2013;13:215-25.

28. Palomar AM, Portillo A, Santibanez P, Mazuelas D, Arizaga J, Crespo A, et al. Crimean-Congo hemorrhagic fever virus in ticks from migratory birds, Morocco. Emerg Infect Dis. 2013;19:260-3.

29. Mitra SS, Buckley PA, Buckley FG, Ginsberg HS. Highly variable acquisition rates of Ixodes scapularis (Acari: Ixodidae) by birds on an Atlantic Barrier Island. J Med Entomol. 2010;47:1019-27.

30. Newman EA, Eisen L, Eisen RJ, Fedorova N, Hasty JM, Vaughn C, Lane RS Borrelia burgdorferi sensu lato spirochetes in wild birds in northwestern California: associations with ecological factors, bird behavior and tick infestation. PLoS One. 2015;10:e0118146.

31. Brinkerhoff RJ, Folsom-O'Keefe CM, Tsao K, Diuk-Wasser MA. Do birds affect Lyme disease risk range expansion of the vector-borne pathogen Borrelia buradorferi. Front Ecol Environ 2011;9:103-10.

32. Tsui PY, Tsai KH, Weng MH, Hung YW, Liu YT, KY H, et al. Molecular detection and characterization of spotted fever group rickettsiae in Taiwan. Am J Trop Med Hyg. 2007;77:883-90.

33. Tsai $\mathrm{KH}$, Wang $\mathrm{HC}$, Chen $\mathrm{CH}$, Huang JH, HY L, CL S, Shu PY. Isolation and identification of a novel spotted fever group rickettsia, strain IG-1, from Ixodes granulatus ticks collected on Orchid Island (Lanyu), Taiwan. Am J Trop Med Hyg. 2008;79:256-61.
34. Kuo CC, Huang JL, Shu PY, Lee PL, Kelt DA, Wang HC. Cascading effect of economic globalization on human risks of scrub typhus and tick-borne rickettsial diseases. Ecol Appl. 2012;22:1803-16.

35. Khatri-Chhetri R, Wang HC, Chen CC, Shih HC, Liao HC, Sun CM, et al. Surveillance of ticks and associated pathogens in free-ranging Formosan pangolins (Manis pentadactyla pentadactyla). Ticks Tick Borne Dis. 2016;7:1238-44.

36. Chu PJ. Epidemiology of Bartonella spp. between Cyclemys flavomarginata and Niviventer coninga in a sympatric ecological environment. MSc thesis. Institute of Veterinary Medicine, National Chung Hsing University; 2011. p. 70. (In Chinese).

37. Tsai YL, Chomel BB, Chang CC, Kass PH, Conrad PA, Chuang ST. Bartonella and Babesia infections in cattle and their ticks in Taiwan. Comp Immunol Microbiol Infect Dis. 2011:34:179-87.

38. Tsai YL, Lin CC, Chomel BB, Chuang ST, Tsai KH, WJ W, et al. Bartonella infection in shelter cats and dogs and their ectoparasites. Vector Borne Zoonotic Dis. 2011;11:1023-30.

39. Chao LL, WJ W, Shih CM. First detection and molecular identification of Borrelia burgdorferi-like spirochetes in Ixodes granulatus ticks collected on Kinmen Island of Taiwan. Am J Trop Med Hyg. 2009;80:389-94.

40. Chao LL, WJ W, Shih CM. Molecular detection of Borrelia valaisiana-related spirochetes from Ixodes granulatus ticks in Taiwan. Exp Appl Acarol. 2010;52: 393-407.

41. Hoogstraal H, Kohls GM. Description, hosts, and ecology of Ixodes kuntzi n. sp., Kuntz's Taiwan flying squirrel tick (Ixodoidea: Ixodidae). J Med Entomol. 1965;2:209-14.

42. Maa TC, Kuo JS. Catalogue and bibliography of ticks and mites parasitic on vertebrates in Taiwan. Quart J Taiwan Mus. 1966;19:373-413.

43. Wilson N. New distributional records of ticks from Southeast Asia and the Pacific (Metastigmata: Argasidae, Ixodidae). Orient Insects. 1970;4:37-46.

44. Hoogstraal H, Santana FJ. Haemaphysalis (Kaiseriana) mageshimaensis (Ixodoidea: Ixodidae): human and wild and domestic mammal hosts, and distribution in Japan, Taiwan, and China. J Parasitol. 1974;60:866-9.

45. Tseng YH. [Ticks of Taiwan and bordering countries.] Bulletin No. 12, Bureau of Commodity Inspection and Quarantine, Ministry of Economic Affairs, Taipei, Taiwan; 1978 (In Chinese).

46. Tseng YH. A catalogue and bibiliography of Acari of Taiwan (Arachnida: Acarina). Taipei, Taiwan: Bureau of Commodity Inspection and Quarantine, Ministry of Economic Affairs; 1982.

47. Hoogstraal H, Wassef HY, Santana FJ, Kuntz RE. Dermacentor (Indocentor) taiwanensis (Acari: Ixodoidea: Ixodidae): hosts and distribution in Taiwan and southern Japan. J Med Entomol. 1986;23:286-8.

48. Robbins RG. The ticks (Acari: Ixodida: Argasidae, Ixodidae) of Taiwan: a synonymic checklist. Proc Entomol Soc Wash. 2005;107:245-53.

49. Kuo CC, Huang CL, Wang HC. Identification of potential hosts and vectors of scrub typhus and tick-borne spotted fever group rickettsiae in eastern Taiwan. Med Vet Entomol. 2011;25:169-77.

50. Shih CM, Chao LL. A catalog of Ixodidae ticks of Taiwan. Taipei: Borhwa Design and Production; 2011.

51. Tsai YL, Shyu CL, Yao CT, Lin JA. The ixodid ticks collected from dogs and other animals in Taiwan and Kinmen Island. Int J Acarol. 2012;38:110-5.

52. Hoogstraal H, Wassef HY. The Haemaphysalis ticks (Ixodoidea: Ixodidae) of birds. 3. H. (Ornithophysalis) subgen. n.: definition, species, hosts, and distribution in the oriental, Palearctic, Malagasy, and Ethiopian faunal regions. J Parasitol. 1973;59:1099-17.

53. Mariana A, Kulaimi BM, Halimaton I, Suhaili ZA, Shahrul-Anuar MS, Zalipah MN, Ho TM. Acarine ectoparasites of Panti Forest Reserve in Johore, Malaysia. Asian Pac J Trop Biomed. 2011;1:1-5.

54. Changbunjong T, Jirapattharasate C, Buddhirongawatr R, Chewajon K, Charoenyongyoo P, Suwanapakdee S, et al. Ectoparasitic fauna of birds, and volant and non-volant small mammals captured at Srinakarin dam, Kanchanaburi, Thailand. Southeast Asian J Trop Med Public Health. 2010;41: $526-35$

55. Lee PF, Ding TS, Hsu FH, Geng S. Breeding bird species richness in Taiwan: distribution on gradients of elevation, primary productivity and urbanization. J Biogeogr. 2004;31:307-14.

56. Clements JF, Schulenberg TS, Iliff MJ, Roberson D, Fredericks TA, Sullivan BL, Wood CL. The eBird/Clements checklist of birds of the world: v2015; 2015.

57. Yamaguti N, Tipton VJ, Keegan HL, Toshiaoka S. Ticks of Japan, Korea, and the Ryukyu islands. Brigh Young Univ Sci Bull Biol Series. 1971;15:1-225.

58. Teng KF, Jiang ZJ. Economic insect Fauna of China. Fasc 39. Acari: Ixodidae. In: Fauna Sinica. Beijing: Science Press; 1991. (In Chinese). 
59. Black WC, Piesman J. Phylogeny of hard- and soft-tick taxa (Acari: Ixodida) based on mitochondrial 16S rDNA sequences. Proc Natl Acad Sci USA. 1994; 91:10034-8.

60. Beati L, Keirans JE. Analysis of the systematic relationships among ticks of the genera Rhipicephalus and Boophilus (Acari: Ixodidae) based on mitochondrial 12S ribosomal DNA gene sequences and morphological characters. J Parasitol. 2001;87:32-48.

61. Basic Local Alignment Search Tool. http://www.ncbi.nlm.nih.gov.

62. Guglielmone AA, Robbins RG, Apanaskevich DA, Petney TN, Estrada-Pena A, Horak IG. The hard ticks of the world. Dordrecht: Springer; 2014.

63. Ishiguro F, Takada N, Masuzawa T, Fukui T. Prevalence of Lyme disease Borrelia spp. in ticks from migratory birds on the Japanese mainland. Appl Environ Microbiol. 2000;66:982-6.

64. Miyamoto K, Masuzawa T, Kudeken M. Tick collection from wild birds and detection of Lyme disease spirochetes from a new avian reservoir in Japan. Med Entomol Zool. 2000;51:221-6.

65. Kuo CC, Shu PY, JJ M, Lee PL, YW W, Chung CK, Wang HC. Widespread Rickettsia spp. infections in ticks in Taiwan. J Med Entomol. 2015;52:1096102.

66. Kitaoka S, Saito Y. Ixodes nipponensis n. sp. (Ixodoidea, Ixodidae), a common cattle tick in Japan. Natl Inst Anim Health Q. 1967;7:74-83.

67. Yun SM, Lee YJ, Choi W, Kim HC, Chong ST, Chang KS, et al. Molecular detection of severe fever with thrombocytopenia syndrome and tick-borne encephalitis viruses in ixodid ticks collected from vegetation, Republic of Korea, 2014. Ticks Tick Borne Dis. 2016;7:970-8.

68. Noh Y, Lee YS, Kim HC, Chong ST, Klein TA, Jiang J, et al. Molecular detection of Rickettsia species in ticks collected from the southwestern provinces of the Republic of Korea. Parasit Vectors. 2017;10:20.

69. Chen X, Yu Z, Guo L, Li L, Meng H, Wang D, et al. Life cycle of Haemaphysalis doenitzi (Acari: Ixodidae) under laboratory conditions and its phylogeny based on mitochondrial 16S rDNA. Exp Appl Acarol. 2012;56: 143-50

70. Takano A, Fujita H, Kadosaka T, Takahashi M, Yamauchi T, Ishiguro F, et al. Construction of a DNA database for ticks collected in Japan: application of molecular identification based on the mitochondrial 16S rDNA gene. Med Entomol Zool. 2014;65:13-21.

71. Rar V, Golovljova I. Anaplasma, Ehrlichia, and "Candidatus Neoehrlichia" bacteria: pathogenicity, biodiversity, and molecular genetic characteristics, a review. Infect Genet Evol. 2011;11:1842-61.

72. Uilenberg G. Babesia - a historical overview. Vet Parasitol. 2006;138:3-10.

73. Barbour AG, Hayes SF. Biology of Borrelia species. Microbiol Rev. 1986;50: 381-400.

74. Sprong $H$, Wielinga PR, Fonville $M$, Reusken $C$, Brandenburg AH, Borgsteede $F$, et al. Ixodes ricinus ticks are reservoir hosts for Rickettsia helvetica and potentially carry flea-borne Rickettsia species. Parasit Vectors. 2009;2:41

75. Obiegala A, Pfeffer M, Pfister K, Karnath C, Silaghi C. Molecular examinations of Babesia microti in rodents and rodent-attached ticks from urban and sylvatic habitats in Germany. Ticks Tick Borne Dis. 2015;6:445-9.

76. Palomar AM, Portillo A, Santibáñez P, Mazuelas D, Roncero L, Gutiérrez Ó, Oteo JA. Presence of Borrelia turdi and Borrelia valaisiana (Spirochaetales: Spirochaetaceae) in ticks removed from birds in the north of Spain, 20092011. J Med Entomol. 2017;54:243-6.

77. Hanincová K, Taragelová V, Koci J, Schäfer SM, Hails R, Ullmann AJ, et al. Association of Borrelia garinii and B. valaisiana with songbirds in Slovakia. Appl Environ Microbiol. 2003;69:2825-30.

78. Norte AC, Lopes de Carvalho I, Núncio MS, Ramos JA, Gern L. Blackbirds Turdus merula as competent reservoirs for Borrelia turdi and Borrelia valaisiana in Portugal: evidence from a xenodiagnostic experiment. Environ Microbiol Rep. 2013;5:604-7.

79. Toma L, Mancini F, Di Luca M, Cecere JG, Bianchi R, Khoury C, et al. Detection of microbial agents in ticks collected from migratory birds in central Italy. Vector Borne Zoonotic Dis. 2014;14:199-205.

80. Yabsley MJ, Shock BC. Natural history of zoonotic Babesia: role of wildlife reservoirs. Int J Parasitol Parasites Wildl. 2013;2:18-31.

81. Fukunaga M, Hamase A, Okada K, Nakao M. Borrelia tanukii sp. nov. and Borrelia turdae sp. nov. found from ixodid ticks in Japan: rapid species identification by 16S rRNA gene-targeted PCR analysis. Microbiol Immunol. 1996;40:877-81.

82. Fukunaga M, Hamase A, Okada K, Inoue H, Tsuruta Y, Miyamoto K, Nakao M. Characterization of spirochetes isolated from ticks (Ixodes tanuki, Ixodes turdus, and Ixodes columnae) and comparison of the sequences with those of Borrelia burgdorferi sensu lato strains. Appl Environ Microbiol. 1996;62:2338-44.
83. Heylen D, Tijsse E, Fonville M, Matthysen E, Sprong H. Transmission dynamics of Borrelia burgdorferi s.l. in a bird tick community. Environ Microbiol. 2013;15:663-73.

84. Hasle G, Bjune GA, Midthjell L, Røed KH, Leinaas HP. Transport of Ixodes ricinus infected with Borrelia species to Norway by northward-migrating passerine birds. Ticks Tick Borne Dis. 2011;2:37-43.

85. Gryczyńska A, Welc-Falęciak R. Long-term study of the prevalence of Borrelia burgdorferi s.I. infection in ticks (Ixodes ricinus) feeding on blackbirds (Turdus merula) in NE Poland. Exp Appl Acarol. 2016;70:381-94.

86. Norte AC, Araújo PM, da Silva LP, Tenreiro PQ, Ramos JA, Núncio MS, et al. Characterization through multilocus sequence analysis of Borrelia turdi isolates from Portugal. Microb Ecol. 2015;72:831-9.

87. Palomar AM, Santibáñez P, Mazuelas D, Roncero L, Santibáñez S, Portillo A, Oteo JA. Role of birds in dispersal of etiologic agents of tick-borne zoonoses, Spain, 2009. Emerg Infect Dis. 2012;18:1188-91.

88. Stanek G, Reiter M. The expanding Lyme Borrelia complex - clinical significance of genomic species? Clin Microbiol Infect. 2011;17:487-93.

89. Ismail N, Bloch KC, McBride JW. Human ehrlichiosis and anaplasmosis. Clin Lab Med. 2010;30:261-92.

90. Little SE. Ehrlichiosis and anaplasmosis in dogs and cats. Vet Clin North Am Small Anim Pract. 2011;40:1121-40.

91. Eshoo MW, Carolan HE, Massire C, Chou DM, Crowder CD, Rounds MA, et al. Survey of Ixodes pacificus ticks in California reveals a diversity of microorganisms and a novel and widespread Anaplasmataceae species. PLoS One. 2015;10:e0135828.

92. Machado RZ, André MR, Werther K, de Sousa E, Gavioli FA, Alves Junior JRF. Migratory and carnivorous birds in Brazil: reservoirs for Anaplasma and Ehrlichia species? Vector Borne Zoonotic Dis. 2012;12:705-8.

93. Yang J, Liu Z, Niu Q, Tian Z, Liu J, Guan G, et al. Tick-borne zoonotic pathogens in birds in Guangxi, Southwest China. Parasit Vectors. 2015;8:637.

94. Sándor AD, Kalmár Z, Matei I, lonică AM, Mărcuțan D. Urban breeding corvids as disseminators of ticks and emerging tick-borne pathogens. Vector Borne Zoonotic Dis. 2017:17:152-4.

95. Kang YJ, Diao XN, Zhao GY, Chen MH, Xiong Y, Shi M, et al. Extensive diversity of Rickettsiales bacteria in two species of ticks from China and the evolution of the Rickettsiales. BMC Evol Biol. 2014;14:167.

96. Parola P, Inokuma H, Camicas JL, Brouqui P, Raoult D. Detection and identification of spotted fever group rickettsiae and ehrlichiae in African ticks. Emerg Infect Dis. 2001;7:1014-7.

97. Fournier PE, Fujita H, Takada N, Raoult D. Genetic identification of rickettsiae isolated from ticks in Japan. J Clin Microbiol. 2002:40:2176-81.

98. Inokuma H, Ohashi M, Tanabe S, Miyahara K. Prevalence of tick-borne Rickettsia and Ehrlichia in Ixodes persulcatus and Ixodes ovatus in Tokachi district, eastern Hokkaido, Japan. J Vet Med Sci. 2007;69:661-4.

99. Ishiguro F, Takada N, Fujita H, Noji Y, Yano Y, Iwasaki H. Survey of the vectorial competence of ticks in an endemic area of spotted fever group rickettsioses in Fukui prefecture, Japan. Microbiol Immunol. 2008;52:305-9.

100. Parola P, Miller RS, McDaniel P, Telford SR, Rolain JM, Wongsrichanalai C, et al. Emerging rickettsioses of the Thai-Myanmar border. Emerg Infect Dis. 2003;9:592-5.

101. Phongmany S, Rolain JM, Phetsouvanh R, Blacksell SD, Soukkhaseum V, Rasachack B, et al. Rickettsial infections and fever, Vientiane, Laos. Emerg Infect Dis. 2006;12:256-62.

102. Igolkina Y, Bondarenko E, Rar V, Epikhina T, Vysochina N, Pukhovskaya N, et al. Genetic variability of Rickettsia spp. in Ixodes persulcatus ticks from continental and island areas of the Russian Far East. Ticks Tick Borne Dis. 2016;7:1284-9.

103. Inokuma H, Seino N, Suzuki M, Kaji K, Takahashi H, Igota H, Inoue S. Detection of Rickettsia helvetica DNA from peripheral blood of sika deer (Cervus nippon yesoensis) in Japan. J Wildl Dis. 2008:44:164-7.

104. Sashika M, Abe G, Matsumoto K, Inokuma H. Molecular survey of rickettsial agents in feral raccoons (Procyon lotor) in Hokkaido, Japan. Jpn J Infect Dis. 2010;63:353-4.

105. Parola P, Paddock CD, Socolovschi C, Labruna MB, Mediannikov O, Kernif T, et al. Update on tick-borne rickettsioses around the world: a geographic approach. Clin Microbiol Rev. 2013;26:657-702.

106. Hornok S, Kováts D, Csörgő T, Meli ML, Gönczi E, Hadnagy Z, et al. Birds as potential reservoirs of tick-borne pathogens: first evidence of bacteraemia with Rickettsia helvetica. Parasit Vectors. 2014;7:128.

107. Berthová L, Slobodník V, Slobodník R, Olekšák M, Sekeyová Z, Svitálková Z, et al. The natural infection of birds and ticks feeding on birds with Rickettsia spp. and Coxiella burnetii in Slovakia. Exp Appl Acarol. 2016;68:299-314. 
108. Simser JA, Palmer AT, Fingerle V, Wilske B, Kurtti TJ, Munderloh UG. Rickettsia monacensis sp. nov., a spotted fever group rickettsia, from ticks (Ixodes ricinus) collected in a European city park. Appl Environ Microbiol. 2002;68:4559-66.

109. Ye X, Sun Y, Ju W, Wang X, Cao W, Vector WM. Competence of the tick Ixodes sinensis (Acari: Ixodidae) for Rickettsia monacensis. Parasit Vectors. 2014;7:512.

110. Sun J, Lin J, Gong Z, Chang Y, Ye X, Gu S, et al. Detection of spotted fever group rickettsiae in ticks from Zhejiang Province, China. Exp Appl Acarol. 2015;65:403-11.

111. Shin SH, Seo HJ, Choi YJ, Choi MK, Kim HC, Klein TA, et al. Detection of Rickettsia monacensis from Ixodes nipponensis collected from rodents in Gyeonggi and Gangwon provinces, Republic of Korea. Exp Appl Acarol. 2013;61:337-47.

112. Malaisri P, Hirunkanokpun S, Baimai V, Trinachartvanit W, Ahantarig A. Detection of Rickettsia and Anaplasma from hard ticks in Thailand. J Vector Ecol. 2015;40:262-8.

113. SS O, Chae JB, Kang JG, Kim HC, Chong ST, Shin JH, et al. Detection of severe fever with thrombocytopenia syndrome virus from wild animals and Ixodidae ticks in the Republic of Korea. Vector Borne Zoonotic Dis. 2016;16:408-14.

114. Suh JH, Kim HC, Yun SM, Lim JW, Kim JH, Chong ST, et al. Detection of SFTS virus in Ixodes nipponensis and Amblyomma testudinarium (Ixodida: Ixodidae) collected from reptiles in the Republic of Korea. J Med Entomol. 2016;53:584-90.

115. Cohen EB, Auckland LD, Marra PP, Hamer SA. Avian migrants facilitate invasions of neotropical ticks and tick-borne pathogens into the United States. Appl Environ Microbiol. 2015;81:8366-78.

116. Sparagano O, George D, Giangaspero A, Špitalská E. Arthropods and associated arthropod-borne diseases transmitted by migrating birds. The case of ticks and tick-borne pathogens. Vet Parasitol. 2015;213:61-6.

117. Scott JD. Studies abound on how far north Ixodes scapularis ticks are transported by birds. Ticks Tick Borne Dis. 2016;7:327-8.

118. Severinghaus LL, Ding TS, Fang WH, Lin WH, Tsai MC, Yen CW. The Avifauna of Taiwan. 2nd ed. Forestry Bureau, Council of Agriculture: Taipei; 2012.

119. Parola P, Roux V, Camicas JL, Baradji I, Brouqui P, Raoult D. Detection of ehrlichiae in African ticks by polymerase chain reaction. Trans $\mathrm{R}$ Soc Trop Med Hyg. 2000;94:707-8

120. Choi YJ, Jang WJ, Kim JH, Ryu JS, Lee SH, Yark KH, et al. Spotted fever group and typhus group rickettsioses in humans, South Korea. Emerg Infect Dis. 2005; 11:237-44

121. Chao LL, Chen YJ, Shih CM. First isolation and molecular identification of Borrelia burgdorferi sensu stricto and Borrelia afzelii from skin biopsies of patients in Taiwan. Int J Infect Dis. 2011;15:e182-7.

122. Simpson VR, Panciera RJ, Hargreaves J, McGrarry JW, Scholes SFE, Bown KJ Birtles BR. Myocarditis and myositis due to infection with Hepatozoon species in pine martens (Martes martes) in Scotland. Vet Rec. 2005;156:442-6.

\section{Submit your next manuscript to BioMed Central and we will help you at every step:}

- We accept pre-submission inquiries

- Our selector tool helps you to find the most relevant journal

- We provide round the clock customer support

- Convenient online submission

- Thorough peer review

- Inclusion in PubMed and all major indexing services

- Maximum visibility for your research

Submit your manuscript at www.biomedcentral.com/submit

) Biomed Central 